\title{
SELF-DEFENCE AGAINST NON-STATE ACTORS: ARE POWERFUL STATES WILLING BUT UNABLE TO CHANGE INTERNATIONAL LAW?
}

\author{
Jutta BRunnéE* and Stephen J ToOpe**
}

\begin{abstract}
Can a few primarily Western States expand the right to selfdefence against non-State actors, incorporating the unwilling or unable standard? Even on a traditional reading of customary law formation, the answer is no because proponents have failed to attract consistent and widespread support. What is more, using our interactional international law approach, we show that efforts to date have not been successful because they have failed to address fundamental rule of law concerns. The current state of world politics has perhaps caught proponents of the unwilling or unable standard in a difficult bind. We suggest how proponents might carefully develop the law on self-defence against nonState actors.
\end{abstract}

Keywords: Public international law, change in law, customary international law, interactional international law, non-State actors, rule of law, self-defence, UN Security Council, unwilling or unable standard, use of force.

\section{INTRODUCTION}

Can powerful States shape international law in their favour? Specifically, can the norm entrepreneurship ${ }^{1}$ of a few strong and committed States change customary international law? In trying to do so, what are the constraints that they may encounter? The continuing military action against Islamic State (IS) in Syria, and the accompanying legal justifications, allow us to examine these

* Professor of Law and Metcalf Chair in Environmental Law, Faculty of Law, University of Toronto, jutta.brunnee@utoronto.ca. We thank Professors Eyal Benvenisti, Harold Koh and Georg Nolte for their critical readings of a draft. Of course, the authors alone are responsible for the views expressed, and for any errors or infelicities.

** Professor of Law and Vice-Chancellor, University of Cambridge, stephen.toope@admin. cam.ac.uk. (Most of the work for this article was undertaken while serving as Director of the Munk School of Global Affairs, University of Toronto.)

1 The concept of 'norm entrepreneurship'-self-conscious attempts by international actors including States to create, shift or destroy norms, including legal norms - is well established in the literature of international relations. See eg M Finnemore and K Sikkink, 'International Norm Dynamics and Political Change' (1998) 52 IntlOrg 887; and JT Checkel, 'The Constructivist Turn in International Relations Theory' (1998) 50 World Politics 324. 
questions in a concrete setting, where both material and rhetorical practices are at play.

After the events of 11 September 2001, there has been growing agreement that States can lawfully invoke a right to self-defence against non-State actors. However, the parameters of that right remain contested. Specifically, what relationship must be shown to exist between the State on whose territory defensive action is taken and a non-State actor operating from that territory? Historically, the required link was one of direct agency: the nonState actor had to be controlled by the State against which defensive action was contemplated. Now, some argue for an extension of that rule, suggesting that a State can be exposed to self-defence action if it is unwilling, or simply unable, to act in prevention of an actual or imminent armed attack perpetrated by non-State actors from its territory.

The 'unwilling or unable' argument shifts the traditions of international law dramatically. Where, once, failing to prevent the use of territory to injure another State would have given rise to State responsibility, ${ }^{2}$ and a right to take countermeasures short of force, now it is claimed that the same situation can trigger a right to self-defence. In effect, the requirement of attribution of the actions of a non-State actor to a State is eliminated. ${ }^{3}$ Instead, the nonState actor's threat or use of force is analysed directly within a 'necessity' paradigm, ${ }^{4}$ typically in situations where a State asserts the threat of an imminent attack.

2 See Corfu Channel Case (United Kingdom of Great Britain and Northern Ireland v Albania) [1949] ICJ Rep 22. And see T Christakis, 'Challenging the "Unwilling or Unable" Test' (2017) 77 Heidelberg Journal of International Law 19, 20 (noting that the 'unwilling or unable' standard 'profoundly alters the nature of the due diligence principle').

3 See JA Frowein, 'Article 51 and the Realities of the Present Day World' (2017) 77 Heidelberg Journal of International Law 47, 48 (arguing that 'attribution to the state from whose territory the armed attack is being launched is [not] necessary'). And see N Tsagourias, 'Self-Defence against Non-State Actors: The Interaction between Self-Defence as a Primary Rule and Self-Defence as a Secondary Rule' (2016) 29 LeidenJIL 801, 808-9 (noting that the unwilling or unable test 'moves away from attribution and recognizes non-state actors as independent authors of armed attacks - and direct targets of self-defence - even if such action takes place on the territory of the host state'). More generally, see C Kreß, 'Some Reflections on the International Legal Framework Governing Transnational Armed Conflicts' (2010) 15 Journal of Conflict \& Security Law 245, at 248 (arguing that 'Article 51 of the UN Charter enshrines a right to self-defence against armed attacks carried out by non-State actors even when those acts cannot be attributed to the host state.'); and Gewaltverbot und Selbstverteidigungsrecht nach der Satzung der Vereinten Nationen bei staatlicher Verwicklung in Gewaltakte Privater (Duncker \& Humblot 1995). Other authors have strongly rejected this assessment. See eg G Nolte and A Randelzhofer, 'Article 51' in B Simma et al. (eds), The Charter of the United Nations: A Commentary, Vol II, 3rd edn (Oxford University Press 2012) 1397, at 1414-19 (arguing that attacks by non-State groups are not armed attacks within the meaning of Article 51).

4 See eg A Deeks, "“Unwilling or Unable": Toward a Normative Framework for Extraterritorial Self-Defense' (2012) 52 VaJIntlL 483, 486-8; T Ruys and L Ferro, 'Divergent Views on the Content and Relevance of the Jus ad Bellum in Europe and the United States? The Case of the U.S.-Led Military Coalition against "Islamic State" (10 February 2016) < https://ssrn.com/ abstract $=2731597>8$. See also KN Trapp, 'Back to Basics: Necessity, Proportionality, and the Right of Self-Defence against Non-State Terrorist Actors' (2007) 56 ICLQ 141 (arguing that, as 
In a recent article canvassing the jus ad bellum and jus in bello concerning the law of self-defence against non-State actors, Noam Lubell asserts:

During the past decade, there has been much talk of a supposed new condition for the exercise of self-defense against armed groups, termed the 'unwilling or unable' test. This approach requires that the territorial State ... be either unwilling or unable to prevent the armed attacks conducted by the non-State actor in its territory. The use of the unwilling or unable standard has been criticized for being an unwarranted expansion of the long-standing recognized confines of self-defense.

The debate over this issue risks creating a misguided perception that the notion of unwilling or unable might be presented as a new test under the jus ad bellum designed to replace existing law. This description is inaccurate; rather, if correctly applied, it should be seen as a component within the pre-existing necessity principle. ... The principle of necessity can be read as indicating that force in self-defense must be a last resort. ... The unwilling or unable test is not a new or alternative route for widening the required conditions for exercise of selfdefense; if anything, it is an additional limitation within the test of necessity that must be observed when claiming the right of self-defense against armed groups in the territory of another State. ${ }^{5}$

We agree that the 'unwilling and unable' standard should be understood as a test within the law of necessity. However, as witnessed by the concerted efforts made by key States and supporters to include the formula within the law, as set out in this article, we do not accept that the standard is anodyne in its potential effects. We will show that it threatens to obfuscate the evaluation of necessity and to introduce an unreviewable standard that does not meet widely accepted rule-of-law criteria. As noted above, the standard also attempts to shift the debate from 'attribution' to necessity when there does not appear to be widespread support for that consequential move.

The goal underlying the law of self-defence has always been to provide an objective threshold for action. That goal explains the deep concern that invariably arises in relation to expansive interpretations of anticipatory selfdefence, ${ }^{6}$ such as the George W Bush Administration's claims of 'preventive self-defence'. ${ }^{7}$ If, as we will demonstrate, the unwilling or unable standard fails to provide an objective standard for the invocation of self-defence, it could still be that self-defence against non-State actors is justified as 'necessary' in some cases. But that policy debate must be distinguished from

in all claims of self-defence, in relation to non-State actors the key conditions are necessity and proportionality).

5 N Lubell, 'Fragmented Wars: Multi-Territorial Military Operations against Armed Groups' (2017) 93 International Law Studies 215, 219-20 (footnotes and a fictional scenario removed from quote).

${ }^{6}$ See text accompanying notes $87-88$. 785 . 
the legal question: is the unwilling or unable standard currently part of customary international law? Our goal in this article is to assess the current legal status of the standard and to suggest what may be required to carefully expand the law of self-defence against non-State actors.

A few important States are actively promoting the unwilling or unable trigger for self-defence against non-State actors. They often do so by conflating policy arguments and analysis of State practice. Many doctrinal assessments do the same thing. There is a curious mutual referencing system amongst a small number of States, former State officials, and other commentators that needs to be critically evaluated. Whatever the policy merits of the unwilling or unable standard - and we acknowledge that there are merits as a way to understand necessity - the evidence does not support the existence of that standard in current customary law. We argue below that if the 'unwilling and unable' standard is to become part of customary international law, it will have to be highly circumscribed, and more inclusive and less equivocal support from a wider range of States will be required, matched with a continuing practice supporting the purported rule. We will examine these important questions in Part III of the article, using our interactional law framework, which allows a detailed assessment of legality considerations. ${ }^{8}$ First, we will briefly review the evolution of the law of self-defence in relation to non-State actors (Part II).

\section{LEGAL NORMS ON SELF-DEFENCE AGAINST NON-STATE ACTORS}

The international legal framework on the recourse to armed force consists of the prohibition on the inter-State use of force, existing in customary law and enshrined in Article 2(4) of the UN Charter, and two exceptions to this primary rule: authorization of force by the UN Security Council under Chapter VII of the UN Charter, and self-defence against armed attacks under customary law and enshrined in Article 51 of the Charter. ${ }^{9}$ These components of the normative framework are tightly interwoven.

For the purposes of this article, we focus on the right to use force in selfdefence. The existence of the right is uncontested. However, the precise parameters of self-defence have been subject to long-standing, vigorous

\footnotetext{
8 See J Brunnée and SJ Toope, Legitimacy and Legality in International Law: An Interactional Account (Cambridge University Press 2010); J Brunnée and SJ Toope, 'Interactional International Law and the Practice of Legality' in E Adler and V Pouliot (eds), International Practices (Cambridge University Press 2011) 108; and J Brunnée and SJ Toope, 'Interactional Legal Theory, the International Rule of Law and Global Constitutionalism' in A Lang and A Wiener (eds), Handbook of Global Constitutionalism (Edward Elgar Publishers 2017) 170.

9 In the Obama Administration's last official statement on the law of self-defence, the White House notes a third category of allowable force: 'use of force in an otherwise lawful manner with the consent of the territorial State'. US, White House, 'Report on the Legal and Policy Frameworks Guiding the United States' Use of Military Force and Related National Security Operations' (2016) $<$ https://www.hsdl.org/?abstract\&did=798033> 8. See also Tsagourias (n 3) 809 (observing that 'self-defence and consensual intervention are independent bases for the use of force in international law'). The 'consensual intervention' category does not apply in the Syrian case.
} 
debate, much of which has centred on what constitutes an 'armed attack' that would trigger the right. ${ }^{10} \mathrm{We}$ engage with only one aspect of this debate: whether and when attacks by non-State actors trigger the right to self-defence.

We examine this question in relation to self-defence measures against IS in Syria. ${ }^{11}$ The circumstances under which the actions of non-State fighters can be attributed to a State such that it would be exposed to lawful response action by the victim State have long been questioned. The questions assumed heightened importance after the terrorist attacks of 11 September 2001, and have taken centre stage since the rise of the IS network in Iraq and Syria.

We will illustrate that repeated cycles of legal challenge have resulted in a loosening of the attribution standards and, since 2001, in widespread acceptance that the right to self-defence can be exercised not only against armed attacks that are undertaken by, or attributable to a State, but also against terrorist attacks without State nexus. In the latter context, however, the circumstances under which armed response action can be taken in the territory of another State remain unsettled. While a number of States have advanced the proposition that such action is lawful when the relevant State is unwilling or unable to avert the threat emanating from terrorists operating in its territory, this approach is contested. Many States explicitly resist the formula, others are silent or ambiguous in their reactions, and a handful have advanced an alternative, narrower set of preconditions for lawful response action.

\section{A. Evolution of Legal Practices in the Charter Era}

The UN Charter's use of force framework was a response to World War II and, therefore, enshrined rules that were directed to inter-State conflict. ${ }^{12}$ However, the text of Article 51 does not make reference to 'States' as the origin of the 'armed attack' that gives rise to the right to self-defence, and commentators have suggested that the pre-Charter history does not justify insistence on a strictly inter-State right to self-defence. ${ }^{13}$ Some States and commentators began, as early as the 1960s, to assert that the 'inherent' right of individual or

10 Other key debates, which we leave aside for present purposes, concern necessity and proportionality in the exercise of the right to self-defence. J Gardham, Necessity, Proportionality and the Use of Force by States (Cambridge University Press 2004).

11 We use 'IS' as shorthand for the various manifestations of the terror network also known as the 'Islamic State in Iraq and the Levant' (ISIL) or 'Da'esh.'

${ }^{12} \mathrm{C}$ Gray, International Law and the Use of Force (3rd edn, Oxford University Press 2008) 6; and O Corten, The Law Against War: The Prohibition on the Use of Force in Contemporary International Law (Hart Publishing 2010) 126, 161.

${ }^{13}$ K Trapp, "Actor-Pluralism, the "Turn to Responsibility" and the jus ad bellum: "Unwilling or Unable" in Context' (2015) 2 Journal on the Use of Force and International Law 199, 205. Note that the United States now holds that no State involvement is required for an attack to to qualify as an armed attack triggering the right to self-defence. See US, Department of Defense - Office of the General Counsel, 'Law of War Manual' (June 2015, updated December 2016) <https://www. hsdl.org/?view\&did=797480> 47 ("The inherent right of self-defense, recognized in Article 51 of 
collective self-defence could be exercised against non-State actor attacks, and in States that were harbouring the attackers. ${ }^{14}$ Israel was the first State to assert, in the 1970s, that it could take self-defence measures in a State (Lebanon) that was unwilling or unable to prevent cross-border attacks on Israel emanating from its territory. These interventions, however, were denounced by the Security Council and rejected by many States, albeit for a variety of reasons unrelated to the non-State actor dimension. ${ }^{15}$

The controversy surrounding attacks by non-State actors, and any right of response, was highlighted in the course of the UN General Assembly's efforts to provide authoritative definitions of the use of force. Article $3(\mathrm{~g})$ of the Definition of Aggression qualified the 'sending by or on behalf of a State' of non-State forces as an act of aggression, along with situations involving a State's 'substantial involvement' in the non-State attack. ${ }^{16}$ It is significant that even those States that had urged an expansive definition accepted the premise that only attacks directly supported by States could amount to aggression. ${ }^{17}$

The International Court of Justice (ICJ), in its landmark ruling in the Nicaragua case, ${ }^{18}$ built on the Definition of Aggression to underscore that only attacks by a State, or attributable to a State, could trigger the right to use force in self-defence. The Court took Article 3(g) of the Definition of Aggression as a statement of customary international law, but focused on the 'sending' of irregular forces, requiring that the State had effective control over the armed operation. ${ }^{19}$ In noting that various kinds of assistance to irregular forces might amount to illegal intervention or illegal use of force, but not an 'armed attack', the Court read the 'substantial involvement' aspect of Article 3(g) of the Definition of Aggression narrowly. ${ }^{20}$ The ICJ reaffirmed the narrow construction of the right to self-defence against non-State actor attacks in several subsequent decisions. ${ }^{21}$

However, with the rise of international terrorism in the 1980s, the United States began to assert a broader right to self-defence. Initially it relied primarily on wider tests for State involvement, but, beginning in the 1990s, it

the Charter of the United Nations, applies in response to any "armed attack," not just attacks that originate with States.').

${ }_{14}$ T Ruys, 'Armed Attack' and Article 51 of the UN Charter: Evolutions in Customary Law and Practice (Oxford University Press 2010) 400-1.

16 United Nations General Assembly, Res 3314 (XXIX), 'Definition of Abid 402-4. December 1974) UN Doc A/RES/3314 (XXIX).

${ }_{18}$ Case Concerning Military and Paramilitary Activities in and against Nicaragua (Nicaragua $v$ United States of America) [1984] ICJ Rep 392.

${ }_{20}$ For a discussion of the ICJ's approach, see Tsagourias (n 3) 814-18.

${ }^{21}$ See Legal Consequences of the Construction of a Wall in the Occupied Palestinian Territory (Advisory Opinion) [2004] ICJ Rep 163; Case Concerning Armed Activities on the Territory of the Congo (Democratic Republic of the Congo v Uganda) [2005] ICJ Rep 116. And see Case Concerning Application of the Convention on the Prevention and Punishment of the Crime of Genocide (Bosnia and Herzegovina $v$ Serbia and Montenegro) [2007] ICJ Rep 43. 
advanced the unwilling or unable standard ${ }^{22}$ - a standard that plainly did not meet even the most expansive reading of the 'substantial involvement' criterion in the Definition of Aggression.

After the terrorist attacks of 11 September 2001, the issue of self-defence against non-State actor attacks rose to the top of the international agenda. The Security Council, in resolutions 1368 and 1373, ${ }^{23}$ recognized 'the inherent right of individual or collective self-defence'. However, in their letters to the Security Council indicating that they had begun self-defence operations in Afghanistan, the United States and the United Kingdom did not invoke the unwilling or unable standard. Instead they highlighted the support of Al-Qaeda by the Taliban regime, ${ }^{24}$ effectively deploying the 'substantial involvement' standard. The international response to these operations was generally supportive, but international practice remained ambiguous, fitting narrower self-defence criteria or being accompanied by alternative justifications. ${ }^{25}$

The rise of the IS, a sophisticated, transnational terror network that at one point exercised a substantial degree of territorial control over parts of existing States, prompted other States to take military actions in Iraq and Syria. The interventions by Western States in Syria are particularly relevant for present purposes, as they were undertaken under the banner of self-defence against IS, and in the absence of a link between the IS operations and the Syrian State. Indeed, Syria, with its ally Russia, was fighting its own battles against IS. ${ }^{26}$ Since military action is accompanied by explicit legal justifications, the operations against IS in Syria provide an opportunity to assess both material and rhetorical practices.

In September 2014, the United States and a coalition of several other States began to strike IS in Syria, ${ }^{27}$ from where the network was planning and carrying out cross-border attacks in Iraq along with other terrorist attacks. To find reliable evidence of the legal opinions of the intervening States, we use the official letters they sent to the Security Council, in keeping with their obligation under Article 51 of the UN Charter, to report that they had initiated

22 Ruys (n 14) 421-33. Tibori-Szabó suggests that Iran also invoked the unwilling or unable standard to justify defensive action against Kurdish strongholds in Iraq. K Tibori-Szabó, 'The "Unwilling or Unable" Test and the Law of Self-Defence' in C Paulussen et al. (eds), Fundamental Rights in International and European Law: Public and Private Law Perspectives (Springer 2015) 79, 95.

23 See UN Security Council (UNSC) Res 1368 (12 September 2001) UN Doc S/RES/1368; UNSC Res 1373 (28 September 2001) UN Doc S/RES/1373.

${ }^{24}$ See UNSCOR, 56th Year, UN Doc S/2001/946; and UNSCOR, 56th Year, UN Doc S/2001/ 947.

25 Tibori-Szabó (n 22) 86.

26 AE Kramer and A Barnard, 'Russian Soldiers Join Syria Fight' The New York Times (5 October 2015) < https://www.nytimes.com/2015/10/06/world/middleeast/russian-soldiers-joinsyria-fight.html $>$.

27 US, White House, 'Statement by the President on Airstrikes in Syria' (23 September 2014) $<$ https://obamawhitehouse.archives.gov/the-press-office/2014/09/23/statement-president-airstrikessyria $>$. 
self-defence measures. From a normative perspective these statements help us understand the legal meaning of these concrete actions.

In its letter of September 2014 to the Security Council, the United States asserted that States 'must be able to defend themselves, in accordance with the inherent right to individual and collective self-defence ... when ... the government of the State where the threat is located is unwilling or unable to prevent the use of its territory for ... [terrorist] attacks'. ${ }^{28}$ With this statement, the United States unequivocally went beyond the Nicaragua case and the Definition of Aggression, asserting that the right to self-defence against terrorist actors could be exercised in another State absent 'substantial,' or for that matter any, involvement of the State with the attacks. Canada sent a similarly worded letter in March 2015, ${ }^{29}$ and Australia followed suit in September 2015.30

Some coalition members that participated in operations in Syria, including Bahrain, Jordan, Qatar, Saudi Arabia and the United Arab Emirates, refrained from making explicit legality claims. ${ }^{31}$ Other coalition States, including Belgium, Denmark, and the Netherlands, confined their participation to Iraq, which had consented to strikes in its territory. ${ }^{32}$ The November 2014 letter sent by the United Kingdom, for example, stated only that it was 'taking measures in support of the collective self-defence of Iraq as part of international efforts led by the United States' and that it fully supported international strikes on IS 'sites and military strongholds in Syria' ${ }^{33}$ France, which commenced air strikes in Syria in September 2015, offered only a general Article 51 justification, noting that it had 'taken actions involving the participation of military aircraft in response to attacks carried out by ISIL from the territory of the Syrian Arab Republic'. ${ }^{34}$ Similarly, several Arab States, while supporting or participating in air strikes against IS, have steered clear of invoking the unwilling or unable standard. ${ }^{35}$ A large number of States remained altogether silent on the commencement of strikes against IS in Syria, while a few expressed various kinds of objections. ${ }^{36}$

The situation shifted again, however, after the IS attacks in Paris of 13 November 2015. Shortly after the attacks, the Security Council adopted resolution 2249, which determined that the IS constitutes a 'global and

${ }^{28}$ UNSCOR, 69th Year, UN Doc S/2014/695.

${ }^{29}$ UNSCOR 70th Year, UN Doc S/2015/221.

${ }^{30}$ UNSCOR 70th Year, UN Doc S/2015/745.

${ }^{31}$ Ruys and Ferro (n 4) 6.

32 ibid 11-12. And see P Starski, 'Silence within the Process of Normative Change and Evolution of the Prohibition on the Use of Force - Normative Volatility and Legislative Responsibility' (2016) Max Planck Institute for Comparative Public Law \& International Law (MPIL) Research Paper No 2016-20 <https://papers.ssrn.com/sol3/papers.cfm? abstract_id=2851809> 30; O Flasch, 'The Exercise of Self-Defence against ISIL in Syria: New Insights on the Extraterritorial Use of Force against Non-State Actors' (2016) 3 Journal on the Use of Force and International Law 37, 63.

${ }^{33}$ UNSCOR, 69th Year, UN Doc S/2014/851 (2014). 34 ibid.

${ }_{35}$ Flasch (n 32) 60 (discussing the statements of Bahrain, Jordan, Saudi Arabia and the United Arab Emirates).

${ }^{36}$ Starski (n 32) 31-2. 
unprecedented threat to international peace and security', in part because of 'its control over significant parts and natural resources across Iraq and Syria'. 37 Resolution 2249 went on to call upon States 'to take all necessary measures, in compliance with international law, ... on the territory under the control of ISIL ... in Syria and Iraq'. ${ }^{38}$

In the Security Council debates after the adoption of the resolution, the French representative stated that the French military action in Syria, which France had previously justified as collective self-defence, 'can now also be characterized as individual self-defence, in accordance with Article 51'.39 France did not, however, invoke the unwilling or unable standard advanced in the US Article 51 letter from 2014. The same is true for the UK, which began to extend its military strikes to IS sites in Syria in December 2015. Although Prime Minister David Cameron invoked the unwilling or unable doctrine in two public pronouncements, ${ }^{40}$ the official statement of the British government, contained in the letter of 3 December 2015 to the Security Council, declared only that the UK was 'taking necessary and proportionate measures against ISIL/Daesh in Syria, as called for by the Council in resolution 2249 '. ${ }^{41}$

Resolution 2249 was ambiguous in that it neither authorized the use of force under Chapter VII of the UN Charter nor offered an explicit endorsement of various States' assertions of self-defence, ${ }^{42}$ much less of the unwilling or unable standard. Nonetheless, it played an important role in the continuing process of contestation over the scope of the right to self-defence. Particularly significant in this context was the justification offered by Germany for joining in the collective self-defence operations against the IS in Syria. Germany's letter to the Security Council of 10 December 2015 refers to resolution 2249 and goes on to state that 'ISIL has occupied a certain part of Syrian territory over which the [Syrian] Government ... does not at this time exercise effective control' so that States are 'justified under Article $51 \ldots$ to take necessary measures of self-defence, even without the consent of the

37 UN SC Res 2249 (20 November 2015) UN Doc S/Res/2249, preamble.

38 ibid para 5 (emphasis added). See text accompanying notes $42-48$ for a discussion of the significance of linking any right to self-defence to the territorial control exercised by non-State actors.

39 UNSCOR, 70th Year, 7565th Mtg, Un Doc S/PV.7565 (2015) at 2.

40 See UK, HC, Parliamentary Debates, vol 602, col 1489, 1491 (Prime Minister's Statement 26 November 2015) <https://www.gov.uk/government/speeches/pm-statement-responding-to-facreport-on-military-operations-in-syria>; and UK, 'Prime Minister's Response to the Foreign Affairs Select Committee's Second Report of Session 2015-16: The Extension of Offensive British Military Operations to Syria' (November 2015) <https:/www.gov.uk/government/ uploads/system/uploads/attachment_data/file/480073/PM_Response_to_FAC.pdf $>$.

41 UNSCOR, 70th Year, UN Doc S/2015/928.

42 See D Akande and M Milanovic, 'The Constructive Ambiguity of the Security Council's ISIS Resolution' (EJIL: Talk!, 21 November 2015) < http://www.ejiltalk.org/the-constructive-ambiguityof-the-security-councils-isis-resolution/>. And see M Wood, 'The Use of Force in 2015 with Particular Reference to Syria' (2016) Hebrew University of Jerusalem Legal Studies Research Paper Series 16-05<https://papers.ssrn.com/sol3/papers.cfm?abstract_id=2714064>. 
[Syrian] Government'. ${ }^{43}$ Belgium sent a similarly phrased Article 51 letter in June $2016 .{ }^{44}$

Two aspects of this approach to justification stand out. First, Germany and Belgium emphasized the IS control over parts of Syrian territory and the resultant lack of effective control by Syria of the relevant areas. Second, like a number of other countries, Germany and Belgium linked their self-defence arguments to resolution 2249. In other words, the German and Belgian Article 51 letters provided a narrower justification than the unwilling or unable standard advanced by the United States, a justification that some commentators have likened to a 'lex-ISIL', a special set of rules not applicable to other terror networks who lack 'a territorial basis and military forces capable of making and stabilizing territorial gains' ${ }^{45}$ What is more, by connecting this argument to a Security Council resolution that had confirmed IS control over parts of Syria, the German and Belgian letters appear to suggest that a determination by the Council of the preconditions for self-defence (with the multilateral deliberation that Council involvement entails) is required in the case of non-State actor attacks that cannot be attributed to a State. ${ }^{46}$ Four other States (Denmark, the Netherlands, Norway and the United Kingdom) connected their Article 51 justifications to resolution $2249,{ }^{47}$ albeit not in the specific way that Germany and Belgium had done. ${ }^{48}$

43 UNSCOR, 70th Year, UN Doc S/2015/946. Interestingly, in the justification brought forward by the German government to the Bundestag, there is a reference to military self-defence measures being undertaken in Syria by States allied with Germany 'because the Syrian government is unable/ or unwilling to suppress the IS attacks emanating from its territory' (at 2). The statement appears to be descriptive, but could be read as an endorsement - except that it goes on to refer to UN Security Council Resolution 2249 and specifies that 'the deployment of German forces occurs primarily in and above the operational area of the terror organization IS in Syria, and in the territory of states from which a permission has been obtained from the relevant government ... ' (at 3). These statements seem to align with the position subsequently taken in the German letter to the Security Council. Federal Republic of Germany. Deutscher Bundestag. Drucksache 18/6866 (1 December 2015) [translation by Brunnée]. $\quad{ }_{44}^{4}$ UNSCOR, 71st Year, UN Doc S/2016/523.

$45 \mathrm{~J}$ von Bernstorff, 'Drone Strikes, Terrorism and the Zombie: On the Construction of an Administrative Law of Transnational Executions' (2016) 5(7) European Society of International Law (ESIL) Reflections <http://www.esil-sedi.eu/node/1368>. But see P Urs, 'Effective Territorial Control by Non-State Armed Groups and the Right to Self-Defence' (2017) 77 Heidelberg Journal of International Law 31, 33 (suggesting that the argument is unpersuasive because 'it is not rooted in the attribution of responsibility'). Other commentators have argued that it is not clear that Syria is 'unwilling' to act, given that it has launched military strikes against IS and has invited Russia into its territory to combat IS. It is also not clear that lack of territorial control necessarily proves 'inability' to act; in the same way as external actors, the State could simply launch attacks on the territory that it no longer controls. B Sjöstedt, 'Applying the Unwilling/Unable State Doctrine - Can a State be Unable to Take Action?' (2017) 77 Heidelberg Journal of International Law 39, 41. And see Ruys and Ferro (n 4) 10. Obviously, there are circumstances where 'failed States' are genuinely unable to act.

${ }^{46}$ M Hakimi and J Katz Cogan, 'A Role for the Security Council on Defensive Force?' (2016)

EJIL: Talk! <http://www.ejiltalk.org/a-role-for-the-security-council-on-defensive-force/>.

47 ibid.

48 UNSCOR, 71st Year, UN Doc S/2016/34 (Denmark); UNSCOR, 71st Year, UN Doc S/2016/ 132 (Netherlands); UNSCOR, 71st Year, UN Doc S/2016/513 (Norway). 
The legal picture at the end of May 2017, then, was that some shifts in the material and rhetorical practices concerning the right to self-defence have occurred. Whereas before 11 September 2001, and even up until the recent events involving the IS, there was still considerable support for the idea that only attacks by a State or attributable to a State give rise to a right to use force in self-defence, ${ }^{49}$ it now seems much more widely accepted that nonState actors can commit armed attacks. ${ }^{50}$ The threshold for attributing nonState actor attacks to a State seems to have been lowered, with a more expansive understanding of 'substantial involvement' having gained ground. ${ }^{51}$

However, the preconditions for the exercise of the right to self-defence against a non-State actor attack undertaken from a third State, but not attributable to that State, remain contested..$^{52}$ According to the authors of an October 2016 article surveying State attitudes towards the unwilling or unable standard, ten States (US, UK, Germany, the Netherlands, Czech Republic, Canada, Australia, Russia, Turkey and Israel) explicitly endorsed the test, while three States (Belgium, Iran, South Africa) were doing so implicitly; nine States' positions were classified as ambiguous, and four States (Cuba, Ecuador, Syria and Venezuela) were found to object. ${ }^{53} \mathrm{~A}$ closer look suggests, however, that the survey overstates the support for the unwilling or unable standard and that a consistent pattern of practice concerning the right to self-defence against non-State actors is in fact difficult to discern, even among the States that have participated in military actions against IS in Syria.

Germany and Belgium's positions arguably should not be classified as endorsements, explicit or implicit, of the unwilling or unable test, but as advancing a more specific, narrower standard. ${ }^{54}$ Perhaps surprisingly, even the United Kingdom's position is not unequivocal. As noted above, thenPrime Minister Cameron invoked the 'unwilling and/or unable' standard in public statements on two occasions in November 2015. ${ }^{55}$ Yet, in three separate letters of the UK government to the Security Council explaining the

\footnotetext{
49 M Hakimi, 'Defensive Force against Non-State Actors: The State of Play' (2015) 91 International Law Studies 1, 19.

50 Wood (n 42) 1 and Kreß (n 3). But see, for a more equivocal assessment, Ruys and Ferro (n 4) 8-9, and for a complete rejection of the argument, Nolte and Randelzhofer (n 3).

51 See A Becker-Lorca, "Rules for the "Global War on Terror": Implying Consent and Presuming Conditions for Intervention' (2012) 45 NYUJIntlLaw\&Pol 1, 36-9. J Kammerhofer, 'Positivism' in A Carthy (ed), Oxford Bibliographies: International Law (Oxford University Press 2015) 5-6. And Tibori-Szabó (n 22) 86.

52 See Hakimi (n 49); Hakimi and Katz Cogan (n 46); and Starski (n 32).

53 E Chachko and A Deeks, 'Who is on Board with "Unwilling and Unable"?' (10 October 2016) Lawfare <https://www.lawfareblog.com/who-board-unwilling-or-unable>.

54 But see Ruys and Ferro (n 4) 19, reading the German letter as 'a (barely concealed) reference' to the unwilling or unable standard.

55 See UK, D Cameron, 'PM Statement Responding to FAC Report on Military Operations in Syria' (26 November 2015) <https://www.gov.uk/government/speeches/pm-statementresponding-to-fac-report-on-military-operations-in-syria>; and UK, D Cameron, 'Response to the Foreign Affairs Select Committee's Second Report of Session 2015-16: The Extension of
} 
use of force in Syria and Iraq, the UK government never uses the phrase 'unwilling or unable'. ${ }^{56}$

Even the United States, in a December 2016 'legal and policy framework' document, uses examples to support the unwilling or unable standard that are the narrowest cases, rooted strictly in necessity as traditionally understood. It allows that 'inability perhaps can be demonstrated most plainly where, for example, the State has lost or abandoned effective control over the portion of its territory' from which the non-State actor operates. This articulation is actually close to the German standard, which requires the non-State actor to have effective territorial control. In turn, 'unwillingness might be demonstrated where, for example, a State is colluding with or harboring a terrorist organization operating from within its territory and refuses to address the threat posed by the group'. 57 This statement approximates the old 'substantial involvement' trigger. The use of narrow justifications aligns with the broad assertion in the document that there is no intention to undermine State sovereignty.

What is more, in attempting to anchor the unwilling or unable standard in State practice, the US government cites three governmental letters to the Security Council, attributing one of those letters to France that was actually sent by the Canadian government. ${ }^{58}$ As we noted above, France in fact has never clearly supported the US legal position. ${ }^{59}$ It must also be noted that although the Canadian government of Stephen Harper did support the unwilling or unable standard, the new Justin Trudeau government ceased its air strike operations in Syria and Iraq. ${ }^{60}$ It is not clear that this largely political move can be read as implying a change in legal position. Canada's past statement was evidence of the close alignment of the then-government with the US government's security policies and legal positions. However, the current US and Canadian governments seem to be moving in different directions on several issues. Perhaps the relatively new Canadian government may not yet have had an opportunity to fully review its position on the unwilling or unable standard.

Offensive British Military Operations to Syria' (November 2010) <https://www.gov.uk/ government/uploads/system/uploads/attachment_data/file/480073/PM_Response_to_FAC.pdf >.

${ }_{56}$ See UNSCOR, 69th Year, UN Doc S/2014/851; UNSCOR, 70th Year, UN Doc S/2015/688; and UNSCOR, 70th Year, UN Doc S/2015/928. $\quad 57$ US (n 9) $10 . \quad 58$ ibid 52.

${ }_{59}$ See also Christakis (n 2) 18 (citing a 2016 oral statement by the head of the legal office of the French Ministry of Foreign Affairs, indicating scepticism regarding the 'unwilling or unable' standard). But see Ruys and Ferro (n 4) 13 (citing the French Foreign Minister as stating that there were no legal impediments to strikes in Syria on the basis of Article 51). However, judging from published comments by the French Foreign Office Legal Adviser, France too seems to emphasize the exceptional circumstances involving the Security Council's recognition of the peace and security threat posed by IS, and its resources and territorial control. See F Alabrune, 'Fondements juridiques de l'intervention militaire française contre Daech en Irak et en Syrie' (2016) 120 Revue générale de droit international public 41.

${ }^{60}$ Canada, Office of the Prime Minister, 'Prime Minister Sets New Course to Address Crises in Iraq and Syria and Impacts on the Region' (8 February 2016) $<$ http://pm.gc.ca/eng/news/2016/02/ 08/prime-minister-sets-new-course-address-crises-iraq-and-syria-and-impacts-region>. 
The Czech Republic expressed uncertainty as to whether the unwilling or unable standard was 'part of the customary law international law requirement of necessity', 61 as the United States appears to argue. ${ }^{62}$ Russia has implicitly retreated from its clear endorsement of the unwilling or unable test, at least in the context of Syria. ${ }^{63}$ Finally, the Non-Aligned Movement (NAM), a loose grouping of 120 States, at its September 2016 meeting, reiterated its view that 'consistent with the practice of the UN and international law, as pronounced by the ICJ, Article 51 of the UN Charter is restrictive and should not be re-written or re-interpreted'.64 Although this statement does not specifically refer to the unwilling or unable standard, the NAM has long resisted any attempts to expand the right of selfdefence, or any other unilateral use of force against sovereign States.

There is no doubt that some Western States, led by the the USA and arguably, the UK, are attempting openly to shift the law. They are supported most clearly by Australia and Israel. We salute the willingness of these States to offer explicit legal justifications for their material practice. Frank justification is preferable to simply accreting practices that are never related to transparent legal arguments, leaving commentators and other States to read tea leaves. However, it turns out that the legal statements by important governmental actors such as the UK Attorney General and the US President are more equivocal than they seem to be at first glance. Moreover, there is a curious interplay amongst State officials, former officials writing in their personal capacity and some academic commentators, whereby a small group tries to expand its influence by constantly cross-referencing each other. ${ }^{65}$ Curiously, though, they tend to

61 Chachko and Deeks (n 53) 19 (referring to a Russian Foreign Ministry statement on the illegality of US strikes in Syria). See also Ruys and Ferro (n 4) 9-10 (citing objections to the strikes in Syria by Russia, Iran, Cuba, Venezuela and Syria).

${ }^{63}$ Chachko and Deeks (n 53) 19.

64 Non-Aligned Movement (NAM), 17th Summit of Heads of State and Government of the NonAligned Movement, Final Document (17-18 September 2016) NAM 2016/CoB/DOC.1. Corr.1 $<$ http://cns.miis.edu/nam/documents/Official_Document/XVII-NAM-Summit-Final-OutcomeDocument-ENG.pdf> para 25.2.

${ }^{65}$ See G Keinan, 'Humanising the Right to Self-Defence' (2017) 77 Heidelberg JIL 57 (stating that the "unable or unwilling" test is "backed by decades-long practice"). [This author is a member of the Military Advocate General's Corps of the Israeli Defence Forces, writing in his personal capacity.] And see M Wood, 'Self-Defence Against Non-State Actors - A Practitioner's View' (2017) 77 Heidelberg JIL 75, 76 (stating that "there is considerable support in State practice and writings for the 'unwilling or unable' test" but citing a list of authors, which authors, in turn, identify the practice of only three states as unequivocal - see Deeks (n 4). [Wood is a former UK Foreign Office Legal Advisor; he cites a former Assistant Legal Advisor in the US Department of State (Deeks (n 4)), a former UK Foreign Office Deputy Legal Advisor who coordinated a study on the law of self-defence (E Wilmshurst, 'The Chatham House Principles of International Law on the Use of Force in Self-Defence' (2006) 55 ICLQ 963), another former UK Foreign Office Legal Advisor who, in a private capacity but informed by operational experience, compiled principles of self-defence against non-state actors (D Bethlehem, 'Self-Defence Against an Imminent or Actual Armed Attack by Nonstate Actors' (2012) 106 AJIL 770), and the 'Leiden Policy Recommendations on Counter-terrorism and International Law' (2010) 57 NILR 531 (a set of policy recommendations produced through a consultative process involving three expert working groups; the group on 'the use of force against terrorists' was co-chaired by Wood and included Wilmshurst). Wood has written extensively on the use of force against non-state actors. While 
pass the ball by suggesting that others have supported the new norm, without saying that they themselves support the norm. For example, in a major speech from January 2017, specifically intended to lay out 'when it is lawful to use force in self-defence,' the UK Attorney General did not directly align the United Kingdom with the unwilling or unable test. Instead, he observed that:

A number of [S] tates have also confirmed their view that self-defence is available as a legal basis where the State from whose territory the actual or imminent armed attack emanates is unable or unwilling to prevent the attack or is not in effective control of the relevant part of its territory. ${ }^{66}$

In support of this proposition, he cited the October 2016 survey of State practice that counts the UK among supporters of the unwilling or unable standard. ${ }^{67}$ That survey, however, quotes only the Prime Minister's statements, while acknowledging that the UK letters to the Security Council make no mention of the test. This approach is at best a backhanded endorsement of the 'unwilling or unable' standard.

It would seem that all the advocates of the unwilling or unable standard are conscious of their fragile norm entrepreneurship. Even those States that invoke the standard in their letters to the Security Council preface their justification by saying that States 'must' be able to invoke the unwilling or unable' standard (a policy argument), not that they 'can' (a legal argument). ${ }^{68}$

his writing notes increasing international support for the unwilling or unable standard, he also averts to the caution warranted in equating the Chatham House and Bethlehem Principles with evidence of state practice or opinio juris. See e.g. M Wood, 'The Law on the Use of Force: What Happens in Practice?' (2013) 53 Indian JIL 345, 356. See also E Wilmshurst and M Wood, 'Self-Defence Against Nonstate Actors: Reflections on the "Bethlehem Principles"” (2013) 107 AJIL 390, 393, 395 (noting the proposals involving the unwilling or unable standard 'remain controversial,' even if they are 'rightly' cast as 'increasingly accepted').

The overall tenor of academic commentary is mixed, but it is important to note that many scholars conclude that the unwilling or unable standard has not become part of customary law. See, e.g., M Hakimi, 'Defensive Force against Non-State Actors: The State of Play' (2015) 91 Int'1 L. Studies 1, 30-1; O Corten, 'The "Unwilling or Unable" Test: Has it Been, and Could it be, Accepted?' (2016) 29 Leiden JIL 777, 799; ME O'Connell, 'Dangerous Departures' (2013) 107 AJIL 380, 384; N Tzouvala, 'TWAIL and the "Unwilling or Unable” Doctrine: Continuities and Ruptures' (2016) 109 AJIL Unbound <https://www.asil.org/blogs/symposium-twail-perspectives-icl-ihl-andintervention-twail-and-"unwilling-or-unable"-doctrine> accessed 28 July 2017, 266; TiboriSzabó (n 22) 92-3; and T Christakis (n 2) 22.

66 See eg United Kingdom, Attorney General Speech at International Institute for Strategic Studies: 'The Modern Law of Self-Defence' (11 January 2017) < https://www.justsecurity.org/ wp-content/uploads/2017/01/United-Kingdom-Attorney-General-Speech-modern-law-of-selfdefense-IISS.pdf>

67 Chachko and Deeks (n 53) 11-12.

${ }^{68}$ Even Daniel Bethlehem's much-quoted 'Principles' concerning self-defence against nonstate actors are acknowledged not to 'purport to reflect a settled view of the law or the practice of any state;' rather, they are intended to suggest what 'the appropriate principles are and ought to be.' Bethlehem (n 65) 770 and 775 (the Principles appear at pp. 775-77). The Chatham House Principles, which are the product of consultations with a group of British practitioners and scholars of international law, are prefaced by this caveat: "While the Principles are intended to give a clear representation of the current principles and rules of international law, the law in this area is politically and legally contentious." See Wilmshurst (n 65) 963. 
In our view, the rather mixed, and largely self-referential, practice of a small number of primarily Western States cannot suffice to shift customary law in the face of the silence of a majority of States on the operations against IS in Syria ${ }^{69}$ and the explicit preference of 120 States that the self-defence norm remain a narrow exception. To be more specific, on our reading of the available material and rhetorical State practice, the unwilling or unable standard is currently supported by only five countries: the USA, Israel, Australia and Turkey unequivocally, and the UK ambiguously. Russia and Canada's positions are also ambiguous, with Russia withdrawing its earlier support of the standard in the Syrian case and Canada retreating from its involvement in air strikes. In both cases, these decisions could be seen as politically opportunistic, without any legal intention. Yet these decisions suggest that support for the unwilling or unable standard expressed by each State previously might now be equivocal.

No State from Africa, central or east Asia, or Latin America has even engaged in the debate, other than through support for the general statements on selfdefence of the Non-Aligned Movement. ${ }^{70}$ The NAM statements, however, should be accorded considerable weight, given the sheer number of States endorsing them. Meanwhile, Germany and Belgium are advocating for a more restrictive standard which may be specific to IS's activities in Syria. This constellation of State practice falls far short of the 'widespread and consistent' practice required for the formation of customary international law. ${ }^{71} \mathrm{We}$ see efforts to articulate an opinio juris around the unwilling or unable standard, but here too the examples are highly limited and not entirely consistent.

\section{B. Processes of Legal Change}

World events evidently play a role in prompting and shaping change in law. The rise of the IS, a global terror network with extraordinary resources and capacity to inflict harm, marked a key moment in the long-standing debate around the scope of the right to self-defence. Furthermore, as one commentator put it, IS 'barbarism seems to have opened the floodgates' for acceptance of the unwilling or unable standard. ${ }^{72}$ However, change in material circumstances is not itself sufficient to prompt a shift in a legal framework. Indeed, it may be that unique requirements of law militate against a rapid or radical shift in rules.

69 See Corten (n 12) 785-91; Starski (n 32); and Tibori-Szabó (n 22) 86. See also Deeks (n 4) 549-50 (providing a list of relevant State practice between 1817 and 2011, identifying only Israel, Turkey and the United States as having "specifically invoked the "unwilling or unable" test or a closely related concept'; the UK is listed as well, but only for its argumentation in the context of the Caroline incident).

70 Three NAM-members, Bahrain, Jordan, and the United Arab Emirates, have supported or participated in the strikes against IS, endorsing a self-defence rationale. However, they have not endorsed the unable or unwilling standard. See Flasch (n 32) 64.

71 See text accompanying note 83 .

72 von Bernstorff (n 45) 3. 
The debate around the legal status of the unwilling or unable standard for self defence against non-State actors illustrates this dynamic.

We use the interactional law approach that we have developed over the last 20 years as a useful lens through which to examine why and how change occurs in international law. ${ }^{73}$ It reveals why the various arguments for and against the unwilling or unable standard raise not only policy questions, but fundamental issues of the rule of law. It also offers practical insights into the processes and mechanisms of legal change, providing guidance to norm proponents and resisters. Our framework posits that all legal norms are embedded in, and must be broadly in line with, social norms that arise from the practices and understandings of the society in which they operate. ${ }^{74}$ However, we stress that these shared understandings alone do not make law. What distinguishes legal norms from other types of social norms is not widespread social acceptance alone; nor is it form or pedigree, but adherence to criteria of legality. The most commonly referenced legality criteria were proposed by Lon Fuller, ${ }^{75}$ and we use them as shorthand for 'legality' because of their clarity and cogency. They are central to every effort to define the rule of law and they capture distinctive traits of legal practice. ${ }^{76}$ Finally, norms that are based in shared understandings and that largely meet the criteria of legality must continually be upheld through norm implementation, application and interpretation that also meet the criteria of legality, what we call 'practices of legality'. As we will show, this framework provides a unique perspective on the interplay between the State practice and opinio juris required to form and uphold customary international law.

It is important to remember the context for the debate over the unwilling or unable standard. The prohibition on the use of force, set out now in Article 2(4) of the UN Charter, is a widely shared understanding. It is the primary rule in the field; the right to self-defence is an exception. This rule-exception relationship plays out in all attempts to widen the right to self-defence which have been entangled in persistent contestation, framed by insistence on narrow, verifiable parameters for the exception. As we examine the unwilling or unable standard against the criteria of legality that distinguish law from other forms of social norms, we will focus on the ability of the standard's proponents to reshape the law.

73 See Brunnée and Toope, Legitimacy and Legality (n 8); and Brunnée and Toope, 'Interactional International Law' (n 8).

74 See GJ Postema, 'Implicit Law' (1994) 13 Law and Philosophy 361. Reprinted in WJ Witteveen and W van der Burg (eds), Rediscovering Fuller: Essays on Implicit Law and Institutional Design (Amsterdam University Press 1999) 255. And T Reinold and M Zürn, "Rules about Rules" and the Endogenous Dynamics of International Law: Dissonance Reduction as a Mechanism of Secondary Rule-Making' (2014) 3 Global Constitutionalism 236.

75 LL Fuller, The Morality of Law (revised edn, Yale University Press 1969). Fuller proposed eight criteria (generality, promulgation, non-retroactivity, clarity, non-contradiction, not requiring the impossible, relative constancy over time, and congruence between legal norms and the actions of officials operating under the law). In this discussion, we will address only some of them.

76 Brunnée and Toope, 'Interactional Legal Theory' (n 8). 
The unwilling or unable standard is subject to serious questions in relation to the criteria of legality that legal norms be 'general' - that they be 'rules', rather than ad hoc decisions. While framed in apparently general terms, in practice the unwilling and unable standard singles out a certain category of State. Several commentators have observed that the test has been applied only to States in the Global South ${ }^{77}$ and, we would add, is being promoted primarily by relatively powerful Western States. The test establishes a 'legal framework for ... the semi-periphery' 78 harkening back to the standard of 'civilization' in nineteenth century international law $^{79}$ that enabled European States to accord non-European States a lesser legal status because of how they were 'internally organized' ${ }^{80}$ This critique is powerful to the extent that the effect of the unwilling or unable standard can be to single out even 'willing' States on the basis of relative incapacity. ${ }^{81}$ The sovereignty of such States would be compromised, for they would be presented with the choice of either consenting to operations in their territories or suffering intervention under the banner of selfdefence. ${ }^{82}$ The effect of the German and Belgian attempts to limit, or displace, the nascent unwilling or unable standard is to mitigate the standard's impact on the criterion of generality. The focus on territorial control of the non-State actor, affirmed by a Security Council finding, serves to render highly exceptional the circumstances in which a State that is not actively supporting the non-State actor can be exposed to self-defence measures.

On the standard account, customary law is generated and maintained by a consistent, widespread and representative practice, accompanied by States' conviction that they are legally bound to conduct themselves in accordance with the norm (opinio juris). ${ }^{83}$ Norm-shifts, then, occur when a new standard is being embraced by consistent and widespread practice, accompanied by opinio juris understood, we have argued, as continuing practices of legality. Since much of the content of Article 51 of the UN Charter is provided by customary law, the treaty provision is subject to the inherent dynamism of this process. Although customary law nonetheless tends to be relatively stable, shifting only incrementally, the diffuse, fluid nature of the process makes it harder to identify the precise point at which a new law has been promulgated. ${ }^{84}$ Promulgation matters because legal rules must be known;

77 See DI Ahmed, 'Defending Weak States against the "Unwilling or Unable” Doctrine of SelfDefense' (2013) 9 Journal of International Law and International Relations 1; and Tzouvala (n 65).

${ }^{78}$ Von Bernstorff (n 45) $4 . \quad{ }_{79}$ Becker-Lorca (n 51). ${ }_{80}$ Tzouvala (n 65) 2.

81 Tibori-Szabó (n 22) 89.

${ }^{83}$ North Sea Continental Shelf cases (Germany v Denmark, Germany v Netherlands) [1969] ICJ

Rep 3 [73]-[74]. Our interactional approach to international law suggests that opinio juris is best understood as the need to test subsequent practices surrounding a given legal norm against the criteria of legality. Put differently, continuing practices of legality are evidence of opinio juris. See Brunnée and Toope, Legitimacy and Legality (n 8) 47-8.

${ }^{84} \mathrm{~J}$ Brunnée, 'Sources of International Environmental Law: Interactional Law' forthcoming in $\mathrm{S}$ Besson and J d'Aspremont (eds), Oxford Handbook on the Sources of International Law (Oxford University Press 2017). 
they cannot be secret. Uncertainty as to whether or not a rule actually exists undermines its legality. In the current context it is safe to say that the scope of the right to self-defence against non-State actor attacks remains highly contested, as admitted even by proponents. ${ }^{85}$ Therefore, the unwilling or unable standard has not been promulgated as law, nothwithstanding its invocation by some States to justify their actions in Syria.

Clarity of a rule is another criterion of legality. Much of the struggle over the scope of the right to self-defence revolves around efforts to maintain parameters that are capable of objective assessment. ${ }^{86}$ To be sure, the formulation of the right to self-defence must be sufficiently open-meshed to accommodate a diversity of situations and allow for evolution. Nonetheless, the capacity for objective assessment has been at issue in virtually all the discussions about expanding the right, in contexts that go beyond the case of non-State actors. For example, in his famous account of the Cuban Missile Crisis, the former US State Department Legal Adviser, Abram Chayes, explained why the United States was not relying on the right to self-defence in the following terms: ' $\ldots$ to expand ... [the right to anticipatory] self-defence to include threatening deployments that do not have imminent attack ... as their probable outcome ... is to make the occasion for forceful response essentially a question for unilateral decision that would not only be formally unreviewable, but not subject to intelligent criticism either' ${ }^{9}{ }^{87}$ Similarly, in the current debate about self-defence against non-attributable attacks by non-State actors, it is precisely the fact that the lack of clarity of the unwilling or unable test provides greater room for self-serving claims that has been of concern. ${ }^{88}$ Even strong proponents of the unwilling or unable standard have stressed the importance of objective assessment in the law of self-defence. ${ }^{89}$

The criterion of non-contradiction shines the spotlight on the rule-exception relationship between the rules contained in the UN Charter's use of force provisions. Chayes' observations in the context of anticipatory self-defence apply with equal force in the debate about the scope for self-defence against non-State actor attacks: a wide "construction of "armed attack" could not help but weaken ... normative checks' on how [S]tates behave. ${ }^{90}$ We would add that

\footnotetext{
85 See eg E Wilmshurst, Principles of International Law on the Use of Force by States in SelfDefence (Chatham House 2005) 2, 12.

86 Supporters of the unwilling or unable standard accept that the possibility of objective assessment is required to buttress the standard's legal status. See Bethlehem (n 68) 776 [Principles 11 and 12].

87 A Chayes, The Cuban Missile Crisis (Oxford University Press 1974) 65. Although not the focus of this article, the concern over the proper scope of 'imminence' is very much alive, witness the pre-occupations of two senior legal advisors. See UK Attorney General Speech (n 66); and the Australian Attorney-General, George Brandis, 'The Right to Self-Defence against Imminent Attack in International Law' (Lecture delivered at the T C Beirne School of Law, University of Queensland, 11 April 2017) < https://www.ejiltalk.org/the-right-of-self-defenceagainst-imminent-armed-attack-in-international-law/> (speaking to a Law School audience).

88 See Ahmed (n 77) 14-16; Becker-Lorca (n 51) 92; Deeks (n 4) 488; Bethlehem (n 68) 584; and Tibori-Szabó (n 22) 88.

89 Brandis (n 87).

90 Chayes (n 87) 65 .
} 
an overbroad reading of the self-defence exception would threaten to eviscerate the primary rule, in fact contradicting it. This point has been made elsewhere in powerful terms, with one commentator asking whether embracing the unwilling or unable standard would entail removing the legal constraints on inter-State violence, and whether it would produce 'a creature that can still be called law'.${ }^{91}$

The protracted contestation surrounding the unwilling or unable standard tends to confirm that these concerns are not merely those of academic commentators, but are shared by a great number of States. The inherent contradiction between an expansive right to self-defence and the prohibition on the use of force is among the legality considerations holding back the acceptance of the unwilling or unable standard as a rule of customary international law. Arguably, the same is true for the tension between this standard and the foundational legal principles of sovereignty and nonintervention. ${ }^{92}$

Legal norms should make reasonable demands, not ask the impossible of those to whom they are addressed. For example, in the current context, a sweeping and absolute prohibition on the use of inter-State force would be practically (and politically) unthinkable without appropriate exceptions. This practical point has legal implications. An overly narrow construction of the right to self-defence might be seen as asking States to do the impossible: to suffer attacks and tolerate urgent threats. ${ }^{93}$ For example, the ICJ in the Nicaragua case requires that a State exercise effective control over the armed actions of non-State actors for it to be liable to self-defence action on its territory. Increasingly, this view is seen to be too narrow, demanding an impossibly high proof of linkage before necessary self-defence action can be taken. ${ }^{94}$ Here we have an example of a pull towards legal change resulting from what has become an arguably unreasonable legal constaint.

In the context of the unwilling or unable standard, the need to avoid impossible demands actually pulls in the opposite direction, resisting change to current limitation on the lawful invocation of self-defence. As currently phrased, the standard would make it impossible for States that are willing but unable to take sufficient measures against terrorist attacks from their territory to avoid foreign military intervention. ${ }^{95}$ Either they consent to intervention, or have it forced upon them.

A final criterion of legality is congruence between the purported demands of a rule and its operation in practice. Although the unwilling or unable standard has been invoked by a very small group of States for some time, as we have demonstrated, there does not currently exist a widespread, consistent and representative practice of legality around the standard. We venture to suggest that such a practice is unlikely to develop unless the failures to instantiate the

\footnotetext{
91 Von Bernstorff (n 45) 2, $6 . \quad 92$ Becker-Lorca (n 51) 91-92. $\quad 93$ ibid 90, 93.

94 See eg M Scharf, 'How the War against ISIS Changed International Law' (2016) 48 CaseWResJIntlL 15.

95 Becker-Lorca (n 51) 13.
} 
criteria of legality that we have traced out above are sufficiently addressed, and concerted efforts are made to build wider and more representative support for the unwilling or unable standard. In the conclusion, we will suggest what might be done to open up avenues for inclusive support for this purported legal norm.

\section{CONCLUSION}

Since 11 September 2001, a significant change has taken place in the law of selfdefence. It is now widely accepted that States can exercise the right against attacks or threats posed by non-State actors. A small group of States, led by two Western military powers, the USA and-less clearly - the UK, has been pushing further, arguing that the right to self-defence against non-State actors can be pursued within States that are unwilling or merely unable to preclude attacks from their territory. Jettisoning entirely the previous legal requirement of attribution, the new standard would shape the understanding of 'necessity' to fully justify military action in self-defence within States where non-State actors operate.

Our analysis demonstrates that, to date, this attempt to shift customary international law has not succeeded and, indeed, that it may not succeed at all. ${ }^{96}$ Great caution is warranted before accepting the argument that changes in customary international law can be produced through the practice of a small number of lead-States combined with the alleged acquiescence of a largely silent majority. In any event, State support for the unwilling or unable standard is much weaker than is often asserted by government officials and commentators. In fact, the purported new rule is supported without caveat by only five States (USA, Australia, Israel, Turkey, UK).

Russia invoked the standard in relation to its own actions in the Caucasus, but argued that intervention against IS in Syria was illegal. Canada's recent practice in ending air strike operations in Syria and Iraq at least raises the question of its legal intent, which now requires clarification. Strangely, the UK's support is not unambiguous because statements by senior government figures are not fully congruent with justifications offered in official letters to the Security Council. The Attorney General's recent statement is opaque on this issue. Other States forming part of the anti-IS coalition in Syria are either silent on the unwilling or unable standard, offer generic self-defence justifications, link their actions to UN Security Council resolution 2249 (which makes no reference to self-defence whatsoever), or propose a narrower trigger-standard for self-defence against non-State actors. What is more, the 120-strong Non-Aligned Movement has consistently resisted any attempts to expand the justifications for self-defence.

96 See also Wood, 'The Law on the Use of Force' (n 65) 365 (cautioning that '[e]fforts radically to amend or reinterpret the rules are neither desirable, nor likely to succeed. One or a few States, however powerful, cannot change established rules of international law, Charter-based ones at that'.) 
One must assume that this general approach also applies to claims in relation to non-State actors.

Despite our conclusion that the law has not shifted to support an expansive unwilling or unable justification for self-defence against non-State actors, we acknowledge that the issue is vital, and deserves focussed attention. It is not surprising that two States that have been subjected to recurrent terrorist attacks, Israel and the USA, should be forceful norm entrepreneurs. Nor is it surprising that other States that have traditionally played significant roles in international military actions, such as the UK and Australia, might join in. The puzzle to solve is why there seems to be such a concerted effort to solidify a revised legal framework right now. The Obama statement on the use of force was issued at the tail end of his presidency in December 2016. The statement of the UK Attorney General dates from January 2017, and the Australian Attorney General followed suit in April 2017. A series of articles by former government lawyers had appeared after 11 September 2001, setting the stage for the unwilling or unable standard of necessity.

One might speculate that academic articles and policy briefs were consciously part of a process of norm entrepreneurship, building up claims around necessity and State practice to validate the unwilling or unable standard. There appears to have been a consensus in the US government (and in Israel) that the standard had to be asserted to avoid an inability to act in the face of real threats. But the precise articulation in the Obama statement may have been an attempt to circumscribe the room to manoeuvre of the incoming administration. What is more, the timing of the UK and Australian interventions is unlikely to have been coincidental. There may well have been a shared sense that a Trump-led government might not take care to articulate, or adhere to, any legal standard. ${ }^{97}$

In other words, proponents of the unwilling or unable standard may be fighting concurrently on two fronts. Obviously, they seek to address the legitimate concern that action needs to be taken to confront IS effectively. But at the same time, they are conscious of the imperative to protect the rule of law at a time when one of the traditional supporters - the United States of America-is retreating from leadership and becoming an unreliable, and unpredictable, partner.

Whatever the motivations, with the exception of the US and Israel, State support for the unwilling or unable standard is half-hearted, even amongst States that are seen as proponents. All formal legal statements, such as letters

\footnotetext{
97 As it turns out any such sense has proved to be well-founded. See eg K Beckerle, 'U.S. Officials Risk Complicity in War Crimes in Yemen' (Just Security, 4 May 2017) <https://www. justsecurity.org/40518/officials-risk-complicity-war-crimes-yemen/>; M Milanovic, 'The Clearly Illegal US Military Strike in Syria' (EJIL: Talk!, 7 April 2017) <https://www.ejiltalk.org/theclearly-illegal-us-missile-strike-in-syria/>; K Tibori-Szabó, 'The Downing of the Syrian Fighter Jet and Collective Self-Defence' (Opinio Juris, 23 June 2017) <http://opiniojuris.org/2017/06/23/ the-downing-of-the-syrian-fighter-jet-and-collective-self-defence/ $>$.
} 
to the UN Security Council and speeches by high ranking legal officers are couched in self-conscious, careful terms. Invocation of the unwilling or unable standard is offset by an overall emphasis on a commitment to the rule of law and clear limitations on the right to self-defence. In an April, 2017 speech at the University of Queensland Law Faculty, The Hon George Brandis, Attorney-General of Australia argued:

Even in the face of today's evolving threats, the rule of law and our commitment to upholding an international rules-based order must remain foundational. And the need for clear legal principles is nowhere more apparent than when it comes to the justification for the use of force.

But where a threat does give rise to a right of self-defence under international law, Australia is firmly of the view that clear rules must be in place to delimit the bounds of the use of that force, and to avoid its abuse. That remains true even as we grapple with entirely novel security threats. ${ }^{98}$

The Attorney-General's speech captures perfectly the conundrum facing proponents of the unwilling or unable standard. Although there is a clearly perceived need for the standard in the face of rising terrorist threats from non-State actors, the desire to protect the rule of law-to ensure that exceptions to the use of force are properly restricted-is also powerful.

Recently, whenever global society has been asked to affirm claimed expansions of the right to self-defence, or indeed of any other justifications for the use of force, the vast majority of States has resisted. For example, although the 2005 World Summit Outcome Document acknowledged the existence of a responsibility to protect, when it came to the use of force for humanitarian purposes, it simply reaffirmed the existing UN Charter framework, requiring Security Council authorization. Similarly, the world rejected the claim to 'preventive self-defence' put forward by the Bush administration after 11 September 2001, reaffirming 'that the relevant provisions of the Charter are sufficient to address the full range of threats to international peace and security'. ${ }^{99}$

Proponents of the unwilling or unable standard face an uphill battle. We can only assume that the efforts to date are intended as a foundation on which to build more widespread support. They might be designed to force States to articulate positions, or be counted as having acquiesced. We have shown, however, that these efforts are weakened by the patchwork of justifications offered in the Syrian case, leading to incoherence. To be successful, future efforts would have to extend well beyond a small group of States, to encompass a cross-section of global society. To state the obvious, the

98 Brandis (n 87). See also UK Attorney General Speech (n 66) 21-2.

99 UNGA, World Summit Outcome Document, UN Doc A/Res./60/1 (2005) para 79. See also, Brunnée and Toope, Legitmacy and Legality (n 8) Ch 6. 
requirements for the formation and evolution of customary international law have not changed.

Our review of the current status of the unwilling or unable standard in the light of our interactional approach to international law, and the criteria of legality, underscores the risks inherent in unreviewable and unclear standards. It suggests that to move the standard forward would require a commitment to generality of the rule, meaning that it must be applicable to all States, not only to those in the global south. Could we imagine the standard being applied to an industrialized country that is willing but proves inept at suppressing transnational terrorism? Might France have invoked the rule to engage in self-defence actions within Belgium after the IS-inspired Paris attacks in November 2016? In addition, the unwilling or unable rule would have to be clear enough to be independently assessed, or 'reviewable'. Although unwillingness to act might be possible to demonstrate simply by pointing to a failure to engage in robust anti-terrorist measures, inability is far more complicated. In the case of Syria itself, how can it be said that the Syrian government is unable to act when it is itself engaged with its ally, Russia, in attacks on IS-controlled areas that have been condemned for their brutality and use of prohibited weapons? ${ }^{100}$

What is more, the unwilling and unable standard cannot be so open-ended that it effectively destroys the overarching rule prohibiting the use of force in international relations. Once an exception is so wide as to eviscerate the rule, the criterion of non-contradiction comes into play. There are no clear parameters constraining when States can invoke the unwilling or unable standard. If de facto, attacks are launched by non-State actors from the territory of a State, that State can be accused of either unwillingness or inability to act. What is the defence against those claims? As concerns reasonableness, the thrust of the argument of proponents of the unwilling or unable standard is that it would be unreasonable to expect States to remain passive in the face of direct attacks from non-State actors. We agree. However, it is also unreasonable to present 'willing but unable' territorial States with a Catch-22 situation: consent to intervention or be subjected to it regardless. Finally, if the unwilling or unable standard is to meet the criterion of promulgation, its scope and content would have to be much more clearly established. Currently, it is not possible to know the content of the legal rule that has been proposed.

These rule of law concerns with the current version of the unwilling or unable standard are profound. This fact helps explain why the standard has not been adopted into customary international law. If proponents are to address these

100 See eg, Y Kawashima (updated by A Sanders-Zakre), 'Timeline of Syrian Chemical Weapons Activity, 2012-2017' (Arms Control Association, 7 April 2017) <https://www.armscontrol.org/ factsheets/Timeline-of-Syrian-Chemical-Weapons-Activity>; and K Calamur, 'How Is Syria Still Using Chemical Weapons?' (The Atlantic, 4 April 2017) <https://www.theatlantic.com/ international/archive/2017/04/syria-chemical-weapons-attack/521883/>. 
concerns, the unwilling or unable standard will have to be further specified and, we believe, significantly limited in scope. It is helpful to refer back to the precise examples offered in the 2016 White House 'legal and policy framework' on the use of force as to when the unwilling or unable standard might be invoked: when a 'State has lost or abandoned effective control over the portion of its territory' from which the non-State actor operates; or where 'a State is colluding with or harboring a terrorist organization operating from within its territory and refuses to address the threat posed by the group'. In other words, the unwilling or unable standard should be limited to what the Germans and Belgians argued in their letters to the Security Council. That is, to self-defence against non-State actors who have effectively displaced State control over territory. Alternatively, to situations where a fairly strong form of 'attribution' is present, where a State is harbouring terrorists and refuses to act against them.

In short, some influential, primarily Western, States are clearly willing to change international law. So far, they have not been able to do so. If proponents of the unwilling or unable standard were ready to limit their claims, to draw them closer to the 'traditional' standards of necessity in selfdefence, one might imagine more States being open to a proposed change in the law. Given the rather lukewarm, often incoherent, arguments put forward in support of the broader claim by norm entrepreneurs to date, being more precise by scaling back and specifying the proposed unwilling or unable standard would seem a plausible way forward. To date, the most promising arguments to foster legal change are those put forward by Germany and Belgium. They speak to many of the legality concerns raised in this article, and might therefore attract more widespread support. 